\title{
PERBUATAN MALADMINISTRASI DALAM PEMBUATAN AKTA JUAL BELI OLEH PPAT DAN AKIBAT HUKUMNYA MENURUT PERATURAN PEMERINTAH NOMOR 24 TAHUN 2016 TENTANG PERATURAN JABATAN PPAT Jo. PERATURAN PEMERINTAH NOMOR 37 TAHUN 1998 TENTANG PERATURAN JABATAN PPAT (STUDI KASUS PUTUSAN PENGADILAN NEGERI JAKARTA SELATAN NOMOR: 129/Pdt.G/2016/PN.Jkt.Sel.)
}

\author{
Cecyllia Tamara B. Schouten \\ (Mahasiswa Program S1 Fakultas Hukum Universitas Tarumanagara) \\ (E-mail: tamara.schouten123@gmail.com)
}

\section{Hanafi Tanawijaya \\ (Corresponding Author)}

(Dosen Fakultas Hukum Universitas Tarumanagara, Meraih Sarjana Hukum dari Fakultas Hukum Universitas Tarumanagara, Magister Hukum dari Fakultas Hukum Universitas Tarumanagara)

(E-mail: hanafitanawijaya@gmail.com)

\begin{abstract}
The Land Deed Official (the PPAT) is a Public Official who is granted part of the authorities by the State in the implementation of land registration and the making of an authentic deed. The certificate must be made based on the deeds of the law by the parties. The deeds of the law based on Article 2 of the Government Regulation Number 37 of 1998, a sale and purchase, swap, gift, inbreng, granting right of building/right of use based on the land property rights, and granting of land mortgage. Based on the ordinance, the authentic deed can be used as evidence in case of dispute. In this case is usually a lot of the contempt of court. This act is called the Maladministration. Maladministration is poor management or regulation, especially in an offical capacity. Maladministration is bias, neglect, inattention, delay, incompetence, ineptitude, arbitrariness and so on and would be long and interesting list. Including abuse of power, unlawful procedures, unfairness and malfunction or incompetence. The author examines the problem using normative legal research methods supported by some interviews with some who are experts in the field of the land and maladministration. This act resulted in the existence of legal consequences. Due to the law could by law or may be cancelled. The sanctions awarded againts to the Land Deed Official who did this deed contained in Ministerial Decree of Agrarian Affairs and Spatial/Head of National Land Authority Number 112/Kep-4.1/iv/2017 Article 6 paragraph (1) include reprimand, warning, skorzing, onzetting even fired from The Land Deed Official membership.
\end{abstract}

Keywords : The Land Deed Official, Maladministration, Legal Consequences, Sanctions 


\section{PENDAHULUAN}

\section{A. Latar Belakang}

Manusia sebagai mahluk individu mempunyai bebagai macam kebutuhan dalam hidupnya dimana kebutuhan tersebut kadangkala bertentangan dengan kebutuhan individu lainnya dan pertentangan tersebut dapat diselesaikan secara secara hukum. Maka dari itu, hukum sangat diperlukan untuk menciptakan ketertiban agar membentuk suatu masyarakat yang teratur. Salah satu kebutuhan yang sangat penting bagi masyarakat Indonesia adalah kebutuhan akan tanah yang dapat dijadikan sebagai tempat tinggal.

Sebutan tanah dalam bahasa dapat dipakai dalam berbagai arti, maka dalam penggunaannya perlu diberi batasan, agar diketahui dalam arti apa istilah itu digunakan. ${ }^{1)}$ Undang-Undang Pokok Agraria pada ayat (1) mengatakan bahwa tanah dalam pengertian yuridis adalah permukaan bumi. Tanah diberikan kepada dan dipunyai oleh orang dengan hak-hak yang disediakan oleh Undang-Undang Pokok Agraria, adalah untuk digunakan atau dimanfaatkan. ${ }^{2)}$ Penggunaan dan pemanfaatan tersebut tidak hanya permukaan bumi saja, didalam ayat (2) UndangUndang Pokok Agraria mengatakan hak-hak atas tanah bukan hanya memberikan wewenang untuk mempergunakan sebagian tertentu permukaan bumi yang bersangkutan, tetapi juga tubuh bumi yang ada dibawahnya dan air serta ruang yang ada diatasnya.

Untuk menciptakan ketertiban dalam bidang pertanahan terutama dalam bidang penyelenggaraan Pendaftaran Tanah dan dalam pembuatan Akta Otentik pemerintah dibantu oleh Pejabat Pembuat Akta Tanah yang selanjutnya disebut PPAT. Pengaturan tentang PPAT diatur dalam beberapa peraturan perundangundangan. Pada Pasal 1 ayat (1) Peraturan Pemerintah Nomor 24 Tahun 2016 Tentang Perubahan Atas Peraturan Pemerintah Nomor 37 Tahun 1998 tentang Peraturan Jabatan Pejabat Pembuat Akta Tanah menyebutkan,

1) Boedi Harsono, Hukum Agraria Indonesia: Sejarah Pembentukan Undang-Undang Pokok Agraria,Isi dan Pelaksanaannya, Cetakan ke-3, (Jakarta: Universitas Trisakti, 2016), hal. 18.

\footnotetext{
2) Ibid., hal. 18 .
} 
"Pejabat Pembuat Akta Tanah, selanjutnya disebut PPAT, adalah pejabat umum yang diberi kewenangan untuk membuat akta-akta otentik mengenai perbuatan hukum tertentu, mengenai hak atas tanah atau Hak Milik Atas Satuan Rumah Susun."3)

Tugas dari PPAT adalah melaksanakan sebagian kegiatan pendaftaran tanah dengan membuat akta sebagai bukti telah dilakukannya perbuatan hukum tertentu mengenai hak atas tanah atau hak milik atas satuan rumah susun yang akan dijadikan dasar bagi pendaftaran perubahan data pendaftaran tanah yang diakibatkan oleh perbuatan hukum itu. ${ }^{4)}$ Perbuatan Hukum yang dimaksud adalah yang terdapat dalam Pasal 2 ayat (2) peraturan Pemerintah Nomor 37 Tahun 1998 tentang Pengaturan Jabatan Pejabat Pembuat Akta Tanah yaitu jual beli, tukar menukar, hibah, Pemasukan ke dalam perusahaan (inberg), pembagian hak bersama, pemberian Hak Guna Bangunan/Hak Pakai atas tanah Hak Milik, pemberian Hak Tanggungan, pemberian Kuasa Pembebanan Hak Tanggungan.

Untuk melaksanakan tugasnya tersebut, PPAT diberikan kewenangan dalam membuat akta otentik mengenai perbuatan hukum yang dimaksud. Melalui aktaakta yang dibuat oleh atau dihadapannya, terkandung suatu beban dan tanggung jawab untuk menjamin kepastian hukum bagi para pihak. Salah satu perbuatan hukum yang dimaksud adalah peralihan hak atas tanah dengan cara jual beli. Pengertian jual beli tanah menurut Hukum Adat yaitu perbuatan hukum penyerahan Tanah untuk selama-lamanya dengan penjual menerima pembayaran sejumlah uang, yaitu harga pembelian. ${ }^{5)}$ Dalam masyarakat Hukum Adat jual beli tanah dilaksanakan secara terang dan tunai. Terang berarti perbuatan hukum jual beli tersebut dilaksanakan dihadapan Kepala Adat dan tunai berarti perbuatan yang dilaksanakan bersamaan dengan pembayaran harga dari pembeli kepada penjual. ${ }^{6)}$ Untuk peralihan hak atas tanah dan hak milik atas satuan rumah susun melalui jual beli, tukar-menukar, hibah, pemasukan data perusahaan dan

3) Indonesia. Peraturan Pemerintah Nomor 24 Tahun 2016 Tentang Perubahan Atas Peraturan Pemerintah Nomor 37 Tahun 1998 tentang Peraturan Jabatan Pejabat Pembuat Akta Tanah

4) Urip Santoso, Pejabat Pembuat Akta Tanah (Perspektif Regulasi, Wewenang, dan sifat Akta), Cetakan-1, (Jakarta: Prenadamedia Group, Januari 2016), hlm.97.

${ }^{5)}$ R.D. Soepomo, Hukum Perdata Adat Jawa Barat, Cetakan Ke- 2, (Jakarta: Penerbitan Djambatan, 1982), hlm. 126.

6) Harun Al-Rashid, Sekilas Tentang Jual-Beli Tanah Berikut Peraturan-Peraturannya, (Jakarta: Ghalia Indonesia, 1986), hal. 51. 
perbuatan hukum pemindahan hak karena lelang dapat didaftarkan jika dibuktikan dengan suatu akta otentik yang dibuat oleh seorang pejabat umum yaitu PPAT. ${ }^{7}$ dengan kata lain untuk melakukan peralihan hak atas tanah harus memenuhi persyaratan oleh peraturan perundang-undangan yang berlaku tanpa melanggar kode etik dan juga peraturan jabatan PPAT serta tata cara dalam pembuatan akta otentik adalah merupakan ketentuan hukum yang memaksa dan prosedur pembuatannya itu harus diikuti dengan setepat-tepatnya tanpa boleh disimpangi sedikitpun.

Biasanya dalam pembuatan Akta Peralihan Jual Beli tanah terdapat penyimpangan atau kesalahan yang dilakukan PPAT dalam pembuatannya. Penyimpangan prosedur tersebut dapat disebut sebagai Maladministrasi. Maladministrasi adalah perilaku atau perbuatan melawan hukum melampaui wewenang, menggunakan wewenang untuk tujuan lain dari yang menjadi tujuan wewenang tersebut, termasuk kelalaian atau pengabaian kewajiban hukum dalam penyelenggaraan pelayanan yang dilakukan oleh penyelenggraan dan pemerintah yang menimbulkan kerugian materiil dan/atau imateriil bagi masyarakat dan orang perseorangan. ${ }^{8)}$

Menurut the European Ombudsman, konsep maladministrasi meliputi kelalaian administratif, penyalahgunaan wewenang, kelalaian atau kesembronoan, prosedur yang tidak sah atau melanggar hukum, memperakukan orang lebih baik dari orang lain atau tidak adil atau tidak cakap, fungsi yang jelek atau tidak berwenang, diskriminasi, penundaan yang dapat dihindarkan dan ketiadaan atau menolak memberikan informasi. ${ }^{9)}$ Beberapa contoh pelanggaran yang sering terjadi dalam praktek pembuatan akta PPAT adalah menandatangani akta jual beli sebelum dilakukan pengecekan sertipikat di Kantor Badan Pertanahan Nasional, Akta Jual Beli tidak dibacakan oleh PPAT secara rinci namun hanya menerangkan isi akta secara garis besar, dan penandatanganan terhadap akta jual beli dilakukan

\footnotetext{
7) Indonesia, Peraturan Pemerintah Nomor 24 Tahun 1997 tentang Pendaftaran Tanah, Pasal 37 ayat (1).

8) Indonesia, Undang-Undang Nomor 37 Tahun 2008 tentang Ombudsman Republik Indonesia, Pasal 1 ayat (3).

9) A'an Efendi dan Freddy Poernomo, Hukum Administrasi, Cetakan ke-1, (Jakarta: Sinar Grafika, 2017), hal. 136.
} 
oleh para pihak tidak secara bersamaan dan tidak ada saksi yang terlibat secara langsung dalam penandatanganan akta. ${ }^{10)}$ Berdasarkan studi kasuh pada Pengadilan Negeri Jakarta Selatan Nomor 129/Pdt.G/2016/PN.Jkt.Sel. dimana Penggugat menjaminkan SHM Nomor 494 kepada Hambawi atas pinjaman uang sebesar Rp 100.000.000,00.- dan tanpa sepengetahuan Penggugat SHM nomor 494 tersebut telah berubah diubah kepemilikannya menjadi nama NG Hui Jang dan seorang PPAT membuat Akta Jual Belinya dengan tanpa prosedur yang seharusnya. PPAT tersebut sudah melakukan perbuatannya itu beberapakali dan menjadi sindikat penipuan sertipikat bersama tergugat lainnya.

Berdasarkan latar belakang tersebut, Penulis tertarik dengan membuat jurnal berjudul Perbuatan Maladministrasi Dalam Pembuatan Akta Jual Beli Oleh PPAT Dan Akibat Hukumnya Menurut Peraturan Pemerintah Nomor 24 Tahun 2016 Tentang Peraturan Jabatan PPAT Jo. Peraturan Pemerintah Nomor 37 Tahun 1998 Tentang Peraturan Jabatan PPAT (Studi Kasus Putusan Pengadilan Negeri Jakarta Selatan Nomor 129/Pdt.G/2016/PN.Jkt.Sel.).

\section{B. Permasalahan}

Berdasarkan uraian latar belakang di atas, maka permasalahan yang hendak dirumuskan adalah:

1. Bagaimanakah akibat hukum atas perbuatan maladministrasi yang dilakukan oleh PPAT dalam membuat AJB No. 33/2004?

2. Bagaimana sanksi terhadap PPAT yang melakukan maladministrasi berdasarkan putusan Pengadilan Negeri Jakarta Selatan Nomor : 129/Pdt.G/2016/PN.Jkt.Sel.?

\section{Metode Penelitian}

Metode penelitian hukum merupakan suatu proses untuk menemukan aturan hukum, prinsip-prinsip hukum, maupun doktrin-doktrin hukum guna menjawab isu hukum yang dihadapi. ${ }^{11)}$

\section{Tipe Penelitian}

\footnotetext{
10) Jurnal Ius, Kajian Hukum dan Keadilan, Vol. IV, April 2016, hal. 67-68.

11) Peter Mahmud Marzuki, Penelitian Hukum, Edisi Pertama, Cetakan Ke-2. (Jakarta: Kencana Prenada Media Group, 2006), hal. 35.
} 
Tipe penelitian yang digunakan dalam penulisan ini adalah metode normatif, yang menganalisis suatu keberlakuan hukum yang dilakukan dengan meneliti bahan-bahan hukum, seperti penelitian terhadap asas-asas hukum, hukum positif, aturan hukum, dan kaedah-kaedah hukum dan menyusun hasil penelitian tersebut secara sistematis. ${ }^{12)}$

\section{Jenis dan Sumber Penelitian}

a. Bahan Hukum Primer

Bahan hukum yang bersifat autoritatif, artinya mempunyai otoritas. $^{13)}$ Bahan hukum primer terdiri atas perundang-undangan, catatan-catatan resmi dalam pembuatan perundang-undangan dan putusan-putusan hakim. ${ }^{14)}$ Bahan hukum primer yang digunakan dalam penulisan ini adalah:

1) Kitab Undang-Undang Hukum Perdata.

2) Undang-Undang Nomor 5 Tahun 1960 tentang Peraturan Dasar Pokok-Pokok Agraria.

3) Undang-Undang Nomor 37 Tahun 2008 tentang

Ombudsman Republik Indonesia.

4) Peraturan Pemerintah Nomor 24 Tahun 1997 tentang Pendaftaran Tanah.

5) Peraturan Pemerintah Nomor 24 Tahun 2016 Tentang Perubahan Atas Peraturan Pemerintah Nomor 37 Tahun 1998 tentang Peraturan Jabatan Pejabat Pembuat Akta Tanah (PPAT).

6) Putusan Pengadilan Negeri Jakarta Selatan Nomor: 129/Pdt.G/2016/PN.Jkt.Sel.

b. Bahan Hukum Sekunder

Bahan kepustakaan berupa buku-buku hukum, karya ilmiah hukum (makalah atau tesis dan disertasi) dan yang berkaitan dengan obyek

12) Ibid., hal. 35.

13) Peter Mahmud Marzuki, Penelitian Hukum ;Edisi Revisi, Cetakan Ke-9. (Jakarta: Kencana Prenada Media Group, 2016)., hal. 181.

${ }^{14)}$ Ibid., hal. 181. 
permasalahan. Data sekunder yang digunakan dalam penulisan ini adalah buku-buku atau literatur-literatur mengenai PPAT dan hukum pertanahan juga buku-buku yang membahas tentang maladministrasi. Setelah bahan hukum sudah dianggap memadai, dapat dilakukan wawancara sebagai bahan pendukung yang akan digunakan untuk melengkapi penulisan ini. Kegunaan bahan hukum sekunder adalah memberikan kepada peneliti semacam "petunjuk" kearah mana peneliti melangkah. ${ }^{15)}$

c. Bahan Non-Hukum

Bahan non- hukum yang dipergunakan dalam penelitian adalah Kamus Lengkap Bahasa Indonesia. Tehnik pengumpulan bahan hukum melalui wawancara serta mempelajari dan mencari peraturan perundangundangan mengenai pemindahan hak atas tanah, peraturan mengenai maladministrasi dan penyalahgunaan wewenang, peraturan perundangundangan yang berkaitan dengan jabatan Pejabat Pembuat Akta Tanah dan juga menelusuri buku-buku hukum (treatises) yang isinya terdapat konsep-konsep hukum. ${ }^{16)}$

\section{Pendekatan Penelitian}

Dengan pendekatan perundang-undangan dan pendektan konseptual.

Kemudian melakukan telaah terhadap isu hukum yang dihadapi. ${ }^{17)}$ Pendekatan Konseptual dilakukan karena penulisan ini tidak beranjak dari aturan hukum yang ada. Hal itu dilakukan karena memang belum atau tidak ada aturan hukum untuk masalah yang dihadapi. ${ }^{18)}$

Pendekatan Undang-Undang (statue approach) adalah pendekatan yang dilakukan dengan menelaah semua peraturan perundang-undangan yang terkait dengan permasalahan yang dihadapi, yang juga merupakan bahan hukum primer dalam penelitian ini. Dalam metode pendekatan perundang-undangan, dapat dikatakan adalah pendekatan dengan menggunakan legislasi dan regulasi. ${ }^{19)}$

\footnotetext{
${ }^{15)}$ Ibid., hal. 196.

${ }^{16)}$ Ibid., hal. 237-239.

17) Ibid., hal. 241.

18) Ibid., hal. 177 .

${ }^{19)}$ Ibid., hal. 137.
} 


\section{Sifat Penelitian}

Sifat penelitian yang digunakan adalah Preskriptif, yang diambil dari doktrin-doktrin, pandangan-pandangan para ahli mengenai bahan-bahan hukum yang telah dikumpulkan.

\section{Teknik Analisis Bahan Hukum}

Teknik analisis bahan hukum yang digunakan dalam metode penelitian ini adalah teknik kualitatif. Dengan pendekatan perundang-undangan dan pendektan konseptual. Kemudian melakukan telaah terhadap isu hukum yang dihadapi. ${ }^{20)}$

\section{PEMBAHASAN}

\section{A. Hasil Penelitian}

Menurut Dr. Endang Pandamdari S.H., CN., M.H. jual beli tanah merupakan perbuatan hukum pemindahan hak atas tanah untuk selama-lamanya dan pada saat itu penjual menyerahkan tanah sedangkan pembeli membayar harga, disini ada kewajiban PPAT untuk mengecek keaslian dari sertipikat yang akan dijual tersebut, artinya data fisik dan data yuridisnya itu sama, maka PPAT baru dapat membuat Akta Jual Beli. Data fisik yang dimaksud adalah keterangan mengenai letak, batas dan luas bidang tanah dan satuan rumah susun yang didaftar, termasuk bangunan yang ada diatasnya, sedangkan data yuridis adalah keterangan mengenai status hukum bidang tanah dan satuan rumah susun yang didaftar, pemegang haknya dan hak pihak lain serta beban-beban yang membebaninya. ${ }^{21)}$

Penulis sangat sependapat dengan beliau, karena sesuai dengan Peraturan Pemerintah Nomor 37 tahun 1998 tentang Peraturan Pejabat Pembuat Akta Tanah Pasal 2 ayat (1) menyebutkan PPAT bertugas pokok melaksanakan kegiatan pendaftaran tanah dengan membuat akta sebagai bukti telah dilakukannya perbuatan hukum tertentu mengenai hak atas tanah atau Hak Milik Atas Satuan Rumah Susun, yang akan dijadikannya dasar bagi pendaftaran perubahan data pendaftaran tanah yang diakibatkan oleh perbuatan hukum itu. Dalam kasus ini, jika PPAT mendalilkan bahwa dirinya juga korban dari NG Hui Jang, harusnya

\footnotetext{
20) Ibid., hal. 241.

${ }^{21)}$ Hasil Wawancara
} 
hakim dapat melihat dari bukti berupa AJB Nomor 33/2004 yang dibuat oleh PPAT Marlina Flora, siapa saksi yang datang dan tandatangan dalam AJB Nomor 33/2004 tersebut.

Menurut Dr. Cut Memi S.H., M.H. perbuatan maladministrasi yang biasa dilakukan oleh PPAT atau Notaris itu misalnya seperti dalam membuat akta waris tidak melalui prosedur yang benar, jadi bisa dikatakan mengaburkan silsilah keluarga yang benar. Kemudian, kadangkala PPAT tidak membacakan isi akta kepada para pihak dan bersifat memihak untuk mendapatkan keuntungan yang lebih. Sering juga terjadi dalam hal penandataganan tidak dihadapan PPAT, padahal sudah ada peraturan yang mengatur akan hal tersebut, yaitu yang terdapat dalam Pasal 22 Peraturan Pemerintah Nomor 37 tahun 1998 tentang Peraturan Pejabat Pembuat Akta Tanah yaitu akta yang dibuat PPAT harus dibacakan atau dijelaskan isinya kepada para pihak dengan dihadiri oleh sekurang-kurangnya dua orang saksi. ${ }^{22)}$ Menurut beliau Perbuatan maladministrasi yang dilakukan oleh PPAT dalam kasus ini bisa dipidana dan sudah pasti Akta yang dibuat adalah batal demi hukum.

Menurut Dr. Dwi Andayani S.H., M.H. pembatalan itu ada dua yaitu batal demi hukum dan dapat dibatalkan. Batal demi hukum adalah sejak semula perbuatan hukum itu tidak pernah dianggap ada atau tidak pernah terjadi, sedangkan dapat dibatalkan adalah perbuatan hukum itu berlaku hanya sampai tanggal dibatalkan, sehingga akibat-akibat yang timbul tetap sah sebelum diadakannya pembatalan. Menurut beliau, perbuatan maladministrasi yang dilakukan oleh PPAT Marlina Flora bukan hanya pelanggaran kode etik tetapi sudah termasuk pelanggaran hukum. Menurut beliau, pelanggaran kode etik dan pelanggaran hukum harus dipisahkan. Pelanggaran etika itu adalah bukan hukum, karena sanksi yang didapat hanya teguran dan peringatan. Sedangkan jika sudah melanggar hukum maka sudah pasti diproses secara hukum baik pidana ataupun perdata. Dengan kata lain etika itu adalah bukan hukum jadi jika melanggar etika

\footnotetext{
${ }^{22)}$ Hasil Wawancara
} 
belum tentu melanggar hukum tetapi jika sudah melanggar hukum sudah tentu melanggar etika juga. ${ }^{23)}$

B. Analisa

\section{Akibat Hukum Atas Perbuatan Maladministrasi yang dilakukan oleh PPAT dalam membuat AJB No. 33/2004}

Akibat hukum merupakan suatu akibat yang ditimbulkan oleh hukum karena suatu perbuatan yang dilakukan oleh subjek hukum. Dalam kasus Putusan Pengadilan Negeri Jakarta Selatan Nomor Perkara 129/Pdt.G/2016/PN.Jkt.Sel. diduga melakukan perbuatan yang berakibat hukum yaitu Perbuatan Maladministrasi. Pengertian Perbuatan Maladministrasi menurut Undang-Undang Nomor 37 Tahun 2008 tentang Ombudsman Republik Indonesia Pasal 1 ayat (3) pengertian Maladministrasi, yaitu:

"maladministrasi adalah perilaku atau perbuatan melawan hukum melampaui wewenang, menggunakan wewenang untuk tujuan lain dari yang menjadi tujuan wewenang tersebut, termasuk kelalaian atau pengabaian kewajiban hukum dalam penyelenggaraan pelayanan yang dilakukan oleh penyelenggraan dan pemerintah yang menimbulkan kerugian materiil dan/atau imateriil bagi masyarakat dan orang perseorangan."

Dari definisi menurut Undang-Undang Nomor 37 Tahun 2008 tentang Ombudsman Republik Indonesia dapat dikatakan perbuatan maladministrasi secara umum adalah suatu perbuatan yang salah, tidak wajar, tidak sopan dan kurang peduli terhadap masalah yang menimpa seseorang yang disebabkan oleh penyalahgunaan kekuasaan, termasuk penggunaan kekuasaan secara semena-mena atau kekuasaan yang digunakan untuk perbuatan yang tidak wajar, tidak adil, intimidatif atau diskriminatif dan tidak patut didasarkan sebagian atau seluruhnya atas ketentuan undang-undang atau fakta dan tidak melakukan suatu sesuai dengan prosedur yang berlaku atau diatur oleh Undang-Undang, serta tidak masuk akal dapat juga diartikan sebagai pelaksanaan kewajiban pemerintah yang buruk atau salah.

\footnotetext{
${ }^{23)}$ Hasil Wawancara
} 
Sependapat dengan Dr. Dwi Andayani S.H., M.H., menurut beliau perbuatan maladmnistrasi sangat luas dan banyak tergantung dari sudut pandang mana kita melihat perbuatannya. Jenis-jenis perbuatan Maladministrasi dapat berupa Daad van Willekeur yaitu perbuatan tanpa dasar hukum atau tindakan semena-mena, Turnamen depou voir yaitu penyalahgunaan kekuasaan atau wewenang dimana seorang pejabat administrasi negara bertindak dan mengeluarkan suatu keputusan dengan menggunakan wewenang jabatannya untuk tujuan lain, Exces de pou voir yaitu tindakan melampaui kewenangan jabatannya. Menurut beliau salah satu penyebab Perbuatan Maladministrasi adalah kelalaian akibat ketidakpedulian terhadap wewenang yang telah diberikan kepadanya.

PPAT sebagai Pejabat Umum memiliki peranan yang penting dalam melakukan perbuatan hukum, baik hukum privat maupun hukum publik. Produk hukum yang dikeluarkan oleh PPAT adalah yang terdapat dalam Pasal 2 ayat (2) Peraturan Pemerintah Nomor 37 Tahun 1998 tentang Peraturan Pejabat Pembuat Akta Tanah, yaitu:

a. Jual Beli

b. Tukar menukar

c. Hibah

d. Pemasukan ke dalam perusahaan (inbreng)

e. Pembagian hak bersama

f. Pemberian Hak Guna Bangunan/Hak Pakai atas Tanah Hak Milik

g. Pemberian Hak Tanggungan

h. Pemberian Kuasa membebankan Hak Tanggungan

Dalam melaksanakan tugasnya mengenai perbuatan hukum yang dimaksud dalam Pasal 2 ayat (2) Peraturan Pemerintah Nomor 37 Tahun 1998 tentang Peraturan Pejabat Pembuat Akta Tanah tersebut, PPAT berwenang membuat akta otentik mengenai hak atas tanah dan Hak Milik Atas Satuan Rumah Susun. Dengan dibuatnya Akta PPAT, maka Akta PPAT tersebut dapat dijadikan landasan dan dasar hukum bagi para pihak dalam melakukan perbuatan hukum mengenai peralihan, pemindahan dan pembebanan hak atas tanah dari pihak pertama kepada pihak kedua. 
Pengertian Akta PPAT terdapat di berbagai macam peraturan perundangundangan maupun pengertian para ahli. Misalnya, pengertian Akta PPAT yang terdapat dalam Penjelasan Pasal 45 ayat (1) Peraturan Pemerintah Nomor 24 Tahun 1997 tentang Pendaftaran Tanah yaitu:

"Akta PPAT merupakan alat membuktikan telah dilakukannya suatu perbuatan hukum. Oleh karena itu, apabila perbuatan hukum itu batal atau dibatalkan, akta PPAT yang bersangkutan tidak berfungsi lagi sebagai bukti perbuatan hukum tersebut. Dalam pada itu apabila suatu perbuatan hukum dibatalkan sendiri oleh pihak-pihak yang bersangkutan, sedangkan perbuatan hukum itu sudah didaftar di Kantor Pertanahan, maka pendaftaran itu tidak dapat dibatalkan. Perubahan data pendaftaran tanah menurut pembatalan perbuatan hukum itu harus didasarkan atas alat bukti lain, misalnya putusan Pengadilan atau Akta PPAT mengenai perbuatan hukum yang baru."

Ada dua esensi dalam definisi Akta PPAT yang terdapat dalam Penjelasan Pasal 45 ayat (1) Peraturan Pemerintah Nomor 24 Tahun 1997 tentang Pendaftaran Tanah. Yang pertama, Akta PPAT adalah sebagai alat pembuktian. Artinya, Akta PPAT tersebut sebagai bukti telah diadakannya perbuatan hukum tertentu antara para pihak mengenai hak atas tanah dan hak milik atas satuan rumah susun juga dapat dijadikan landasan bagi pendaftaran perubahan data pendaftaran tanah di Kantor Pertanahan. Yang kedua, dalam Penjelasan Pasal 45 ayat (1) Peraturan Pemerintah Nomor 24 Tahun 1997 tentang Pendaftaran Tanah, Akta PPAT memuat akibat hukum dari perbuatan hukum yang dilakukan antara para pihak.

Dalam kasus Pengadilan Negeri Jakarta Selatan Nomor Perkara 129/Pdt.G/2016/PN.Jkt.Sel. telah diketahui bahwa PPAT Marlina Flora telah membuat AJB No.33/2004 berdasarkan Sertipikat Hak Milik Nomor 494 yang ternyata masih dalam penguasaan Penggugat dan masih dimiliki Penggugat. PPAT Marlina Flora tidak melakukan prosedur yang seharusnya dalam membuat Akta Jual Beli. Dalam melaksanakan tugasnya, PPAT Marlina Flora harus melakukan kewajiban yang diatur dalam perundang-undangan. 
Menurut Dr. Endang Pandamdari S.H., CN., M.H. peralihan hak atas tanah melalui jual beli adalah perbuatan hukum pemindahan hak atas tanah untuk selama-lamanya dan pada saat itu penjual menyerahkan tanah sedangkan pembeli membayar harga, sependapat dengan beliau jual beli merupakan perbuatan hukum yang bersifat terang dan tunai. Terang yang dimaksud adalah pemindahan hak atas tanah tersebut harus didepan Kepala Adat/Desa atau didepan Pejabat yang bertanggung jawab mengenai keteraturan sehingga diketahui oleh umum. Tunai merupakan pemindahan hak atas tanah itu dilakukan secara serentak mengenai pembayaran harganya Pada sub a bab ini, telah dikatakan bahwa ada kewajiban PPAT untuk mengecek keaslian dari sertipikat yang akan dijual tersebut, artinya data fisik dan data yuridisnya itu harus sama, setelah melakukan pengecekan, PPAT baru dapat membuat Akta Jual Beli.

Dalam persidangan tergugat tidak pernah hadir, akan tetapi pada kasus terdahulu dengan Putusan Nomor 398/Pdt.G/2006/PN.Jkt.Sel jis Putusan Nomor 408/PDT/2007/PT.DKI. Putusan Nomor 2931/K/PDT/2008 yang dialami oleh Saudari Netty Saraswaty Barrung, Tergugat mengakui bahwa adanya permufakatan jahat yang dilakukan oleh dirinya dengan PPAT Marlina Flora yang pada faktanya, Tergugat tidak pernah bertemu ataupun menghadap ke PPAT Marlina Flora dalam membuat Akta Jual Beli. Dalam Persidangan dengan Nomor Perkara 129/Pdt.G/2016/PN.Jkt.Sel. PPAT Marlina Flora tidak dapat memberikan bukti berupa dokumen penting dalam membuat AJB No.33/2004 seperti fotokopi KTP para pihak, kartu keluarga dan dokumen-dokumen pendukung lainnya serta saksi yang hadir dalam penandatanganan AJB No.33/2004.

Padahal sudah jelas diatur dalam Peraturan Perundang-Undangan yang terdapat di Pemerintah Nomor 24 tahun 1997 tentang Pendaftaran Tanah Pasal 38 menyebutkan:

"pembuatan akta harus dihadiri oleh para pihak yang melakukan perbuatan hukum yang bersangkutan dan disaksikan sekurang-kurangnya 2 (dua) orang saksi yang memenuhi syarat untuk bertindak sebagai saksi dalam perbuatan hukum itu."

Kemudian Peraturan Pemerintah Nomor 37 tahun 1998 tentang Peraturan Pejabat Pembuat Akta Tanah Pasal 22 yaitu: 
"Akta yang dibuat PPAT harus dibacakan atau dijelaskan isinya kepada para pihak dengan dihadiri oleh sekurang-kurangnya dua orang saksi sebelum ditandatangani seketika itu juga oleh para pihak, saksi-saksi dan PPAT."

Berdasarkan syarat tersebut esensi dari syarat sahnya pembuatan Akta oleh PPAT adalah para pihak melakukan penandatanganan harus dihadapan PPAT dan harus dihadiri sekurang-kurangnya 2 (dua) orang saksi yang cakap untuk bertondak sebagai saksi dan harus PPAT sendiriah yang membacakan isi dari Akta PPAT tersebut kepada para pihak.

Akibat hukum dari pembuatan AJB Nomor 33/2004 yang dibuat oleh PPAT Marlina Flora adalah batal demi hukum, didukung oleh pendapat Dr. Dwi Andayani S.H., M.H., dan karena PPAT Marlina Flora tidak melakukan tugasnya sesuai dengan prosedur yang berlaku dalam peraturan perundang-undangan, maka ini disebut sebagai Perbuatan Maladministrasi. Sependapat dengan beliau, Penggugat dapat mengajukan permohonan batal demi Hukum di Pengadilan. Batal Demi Hukum terjadi karena syarat sahnya dari suatu perjanjian tidak terpenuhi.

Berdasarkan keterangan Penggugat dalam persidangan, pada faktanya Penggugat tidak pernah menjual dan menandatangani AJB No.33/2004 dihadapan PPAT Marlina Flora dan yang terjadi sebenarnya adalah, data dan tandatangan Penggugat telah dipalsukan oleh NG Hui Jang, dalam pembuatan dan penandatangan AJB No.33/2004, dari fakta hukum yang dikemukakan oleh Penggugat dapat dilihat bahwa unsur dari syarat sahnya suatu perjanjian, karena tidak ada kesepakatan yang terjadi antara Penggugat dan Tergugat mengenai jual beli tanah SHM Nomor 494 tersebut dan tidak adanya kausa yang halal mengenai perbuatan hukum pemindahan hak atas tanah ini, karena NG Hui Jang dan PPAT Marlina Flora telah melakukan permufakatan jahat sebagai sindikat penipuan sertipikat.

Berdasarkan Putusan Hakim di Pengadilan Negeri jakarta Selatan Nomor Perkara 129/Pdt.G/2016/PN.Jkt.Sel yang memutus menyatakan batal demi hukum dan tidak mempunyai kekuatan hukum Akta Jual Beli No.33/2004 yang dibuat dihadapan PPAT Marlina Flora. Putusan Hakim sudah sesuai dengan permohonan penggugat dan peraturan Perundang-Undangan yang berlaku. Batal 
demi hukum adalah sejak semula perbuatan hukum itu tidak pernah dianggap ada atau tidak pernah terjadi. Akibat hukum ini menyebabkan penghentian suatu perikatan dan membawa segala sesuatu kembali seperti semula seperti tidak pernah terjadi suatu perikatan dan para pihak wajib mengembalikan apa yang sudah diterimanya selama jual beli berlangsung.

\section{Sanksi Terhadap PPAT Yang Melakukan Maladministrasi Berdasarkan Putusan Pengadilan Negeri Jakarta Selatan Perkara 129/Pdt.G/2016/PN.Jkt.Sel.}

PPAT sebagai Pejabat Umum juga dapat dikategorikan sebagai Pejabat Publik karena PPAT membantu Badan Pertanahan Nasional dalam melakukan Pendaftaran Tanah, sesuai pendapat yang dikemukakan oleh Dr. Endang Pandamdari S.H., CN., M.H. yang mengutip dari buku Profesor Boedi Harsono bahwa PPAT bisa disebut juga sebagai Pejabat Publik karena PPAT adalah mitra Badan Pertanahan Nasional dalam kegiatan penyelenggaraan pendaftaran tanah yang merupakan kegiatan Eksekutif / Tata Usaha Negara. meskipun Akta yang dibuat oleh PPAT tersebut tidak dapat dikategorikan sebagai Keputusan Tata Usaha Negara karena Akta adalah Relaas yaitu suatu laporan tertulis dari pembuat akta berupa pernyataan bahwa telah terjadi perbuatan hukum yang dilakukan oleh pihak-pihak tertentu. PPAT berhak menolak dan mengabulkan pihak-pihak yang meminta untuk dibuatkan akta mengenai perbuatan hukum yang akan dilakukannya.

Dalam Persidangan Pengadilan Negeri Jakarta Selatan Perkara Nomor 129/Pdt.G/2016/PN.Jkt.Sel, PPAT Marlina Flora menyatakan dirinya juga sebagai korban dari tindak pidana pemalsuan yang dilakukan oleh tergugat. Namun dalam hal ini Hakim harusnya dapat menilai dan melihat bahwa perbuatan PPAT Marlina Flora dan Tergugat tidak hanya melakukan perbuatannya satu kali tetapi sudah terbukti bahwa mereka adalah sindikat penipuan sertipikat. Berdasarkan Putusan terdahulu di Pengadilan Negeri Jakarta Selatan Nomor 398/Pdt.G/2006/PN.Jkt.Sel NG Hui Jang mengatakan bahwa dirinya memang benar bekerja sebagai Pegawai dari Bapak Hambawi dan tidak mengetahui keberadaan Hambawi sampai sekarang dan dirinya mengakui bahwa ada 
kerjasama antara Hambawi, PPAT Marlina dengan dirinya meskipun NG Hui Jang tidak pernah bertemu langsung dengan PPAT Marlina Flora dalam membuat Akta Jual Beli.

harusnya hakim dapat melihat berdasarkan Pengakuan NG Hui Jang bahwa adanya kerjasama antara Hambawi dengan PPAT Marlina Flora. Dalam Persidangan Nomor 129/Pdt.G/2016/PN.Jkt.Sel. PPAT Marlina Flora tidak dapat memberikan bukti yang jelas dan kesaksiannya hanya sekedar mengatakan dirinya juga adalah korban tindak pidana yang dilakukan oleh NG Hui Jang dan Hambawi. Logikanya saja, bagaimana bisa PPAT Marlina Flora membuatkan AJB Nomor 33/2004 tersebut jika NG Hui Jang tidak pernah bertemu dengan dirinya? Sebagai PPAT sudah seharusnya dituntut melaksanakan tugas dan kewajibannya secara Profesional dan mandiri, sesuai Keputusan Menteri Agraria dan Tata Ruang/Kepala Badan Pertanahan Nasional Nomor 112/KEP-4.1/IV/2017 tanggal 27 April 2017 tentang Peraturan Kode Etik Ikatan Pejabat Pembuat Akta Tanah Pasal 3 menyebutkan:

"Dalam rangka melaksanakan tugas jabatan para PPAT serta PPAT Pengganti ataupun dalam kehidupan sehari-hari, setiap PPAT diwajibkan untuk:

a. berkepribadian baik dan menjunjung tinggi martabat dan kehormatan PPAT;

b. menjunjung tinggi dasar negara dan hukum yang berlaku serta bertindak sesuai dengan makna sumpah jabatan dan kode etik;

c. berbahasa Indonesia secara baik dan benar;

d. mengutamakan pengabdian kepada kepentingan masyarakat dan Negara;

e. memiliki perilaku profesional dan ikut berpartisipasi dalam pembangunan nasional, khususnya di bidang hukum;

f. bekerja dengan penuh rasa tanggung jawab, mandiri, jujur, dan tidak berpihak;

g. memberi pelayanan dengan sebaik-baiknya kepada masyarakat yang memerlukan jasanya; 
h. memberikan penyuluhan hukum kepada masyarakat yang memerlukan jasanya dengan maksud agar masyarakat menyadari dan menghayati hak dan kewajibannya sebagai warga negara dan anggota masyarakat;

i. memberikan jasanya kepada anggota masyarakat yang tidak atau kurang mampu secara cuma-cuma;

j. bersikap saling menghormati, menghargai serta mempercayai dalam suasana kekeluargaan dengan sesama rekan sejawat;

k. menjaga dan membela kehormatan serta nama baik korps PPAT atas dasar rasa solidaritas dan sikap tolong menolong secara konstruktif;

1. bersikap ramah terhadap setiap pejabat dan mereka yang ada hubungannya dengan pelaksanaan tugas jabatannya;

m. menetapkan suatu kantor, dan kantor tersebut merupakan satu-satunya kantor bagi PPAT yang bersangkutan dalam melaksanakan tugas jabatan sehari-hari;

n. melakukan registrasi, memperbaharui profil PPAT, dan melakukan pemutakhiran data PPAT lainnya di Kementerian Agraria dan Tata Ruang/Badan Pertanahaan Nasional;

Menurut pendapat Dr. Cut Memi S.H., M.H, Perbuatan Maladministrasi yang biasa dilakukan oleh PPAT yang juga berprofesi sebagai Notaris adalah misalnya seperti dalam membuat akta waris tidak melalui prosedur yang benar, jadi bisa dikatakan mengaburkan silsilah keluarga yang benar. Kemudian, kadangkala PPAT tidak membacakan isi akta kepada para pihak dan bersifat memihak untuk mendapatkan keuntungan yang lebih. Sering juga terjadi dalam hal penandataganan tidak dihadapan PPAT. Sanksi terhadap PPAT dapat dikelompokkan menjadi dua jenis yaitusanksi administratif dan sanksi denda. Sanksi administratif yang terdapat pada Keputusan Menteri Agraria dan Tata Ruang/Kepala Badan Pertanahan Nasional Nomor 112/Kep-4.1/IV/2017 pada Pasal 6 ayat (1) yaitu Sanksi yang dikenakan terhadap PPAT dapat berupa teguran, peringatan, skorsing atau pemecatan sementara, kemudian onzetting atau pemecatan dari anggota IPPAT, dan yang terakhir dengan pemberhentian dengan tidak hormat dari keanggotaan perkumpulan IPPAT. Sedangkan sanksi denda 
PPAT sebelum menandatangani akta tidak menyerahkan bukti setoran pajak dan membayar denda sebesar Rp7.500.000,00.- untuk setiap pelanggaran kemudian tidak melaporkan pembuatan akta perolehan atas tanah dan/atau bangunan kepada Direktorat Jenderal Pajak, dalam pelanggaran ini, PPAT harus membayar denda sebesar Rp250.000,00.- untuk setiap laporan.

Menurut Dr. Dwi Andayani S.H., M.H. perbuatan maladministrasi yang dilakukan oleh PPAT Marlina Flora bukan hanya pelanggaran kode etik tetapi sudah termasuk pelanggaran hukum, bahkan menurut Dr. Cut Memi S.H., M.H PPAT Marlina Flora dapat dipidana karena telah melakukan pelanggaran hukum.

Berdasarkan Peraturan Kepala Badan Pertanahan Nasional Republik Indonesia Nomor 1 Tahun 2006 tentang Ketentuan Pelaksanaan Peraturan Pemerintah Nomor 37 Tahun 1998 tentang Peraturan Jabatan Pejabat Pembuat Akta Tanah Pasal 28 ayat (1) mengatakan

"PPAT diberhentikan dengan hormat dari jabatannya oleh Kepala Badan karena:

a. Permintaan sendiri

b. Tidak lagi mampu menjalankan tugas karena keadaan kesehatan badan atau kesehatan jiwanya, setelah dinyatakan oleh tim pemeriksa kesehatan berwenang atas permintaan Kepala Badan atau pejabat yang ditunjuk

c. Melakukan pelanggaran ringan terhadap larangan atau kewajiban sebagai PPAT

d. Diangkat sebagai PNS atau anggoa TNI/POLRI"

Pelanggaran ringan yang dimaksud dalam ayat (1) huruf c terdapat dalam Pasal 28 ayat (3) yaitu:

"pelanggaran ringan sebagaimana dimaksud pada ayat (1) huruf c antara lain:

a. Memungut uang jasa melebihi ketentuan peraturan Perundang-Undangan.

b. Dalam waktu dua bulan setelah berakhirnya cuti tidak melasanakan tugasnya kembali sebagaimana dimaksud dalam Pasal 42 ayat (5).

c. Tidak menyampaikan laporan bulanan mengenai akta yang dibuatnya sebagimana yang dimaksud dalam Pasal 62.

d. Merangkap jabatan sebagaimana dimaksud dalam Pasal 30 ayat (1).

e. Dan lain-lain yang ditetapkan oleh Kepala Badan.” 
Sedangkan pemberhentian PPAT dengan cara tidak hormat terdapat dalam Pasal 28 ayat (2) yaitu:

"PPAT diberhentikan dengan tidak hormat dari jabatannya oleh Kepala Badan, karena:

a. Melakukan pelanggaran berat terhadap larangan atau kewajiban sebagai PPAT

b. Dijatuhi hukuman kurungan/penjara karena melakukan kejahatan perbuatan pidana yang diancam hukuman kurungan atau penjara paling lama lima tahun atau lebih berat berdasarkan putusan pengadilan yang sudah mempunyai kekuatan hukum tetap.

c. Melanggar Kode Etik profesi.

Pelanggaran berat yang dimaksud pada ayat (2) huruf a terdapat dalam Pasal 28 ayat (4), yaitu:

"Pelanggaran berat sebagaimana yang dimaksud pada ayat (20 huruf a antara lain:

a. Membantu melakukan permufakatan jahat yang mengakibatkan sengketa atau konflik petanahan

b. Melakukan pembuatan akta sebagai permufakatan jahat yang mengakibatkan sengketa atau konflik pertanahan

c. Melakukan pembuatan akta diluar daerah kerjanya kecuali yang dimaksud dalam Pasal 4 dan Pasal 6 ayat (3)

d. Memberikan keterangan yang tidak benar didalam akta yang mengakibatkan sengketa atau konflik pertanahan

e. Membuka kantor cabang atau perwakilan atau bentuk lainnya yang terletak diluar dan atau didalam daerah kerjanya sebagaimana dimaksud dalam Pasal 46

f. Melanggar sumpah jabatan sebagai PPAT

g. Pembuatan akta PPAT yang dilakukan, sedangkan diketahui oleh PPAT yang bersangkutan bahwa para pihak yang berwenang melakukan perbuatan hukum atau kuasanya sesuai peraturan perundang-undangan tidak hadir dihadapannya. 
h. Pembuatan akta mengenai hak atas tanah atau Hak Milik atas Satuan Rumah Susun yang oleh PPAT yang bersangkutan diketahui masih dalam sengketa yang mengakibatkan penghadap yang bersangkutan tidak berhak melakukan untuk perbuatan hukum yang dibuktikan dengan akta

i. PPAT tidak membacakan aktanya dihadapan para pihak maupun pihak yang belum atau tidak berwenang melakukan perbuatan sesuai akta yang dibuatnya.

j. PPAT membuat akta dihadapan para pihak yang tidak berwenang melakukan perbuatan hukum sesuai akta yang dibuatnya

k. PPAT membuat akta dalam masa dikenakan sanksi pemberhentian sementara atau dalam keadaan cuti

1. Lain-lain yang dietapkan oleh Kepala Badan"

Dalam kasus ini, sudah jelas bahwa PPAT Marlina Flora telah melakukan pelanggaran berat dalam menjalankan tugas dan kewenangannya. PPAT Marlina Flora telah melakukan perbuatan Maladministrasi dengan cara telah membantu Hambawi menjalankan permufakatan jahat dengan membuat Akta Jual Beli Nomor 33/2004 berdasarkan SHM Nomor 494 tersebut yang mengakibatkan kerugian bagi Penggugat. PPAT Marlina Flora juga tidak melakukan penandatanganan di hadapan para pihak, sudah pasti tidak membacakan isi akta dihadapan para pihak. Pengertian permufakatan jahat memang tidak di sebutkan dalam peraturan perundang-undangan terkait, akan tetapi Pengertian permufakatan jahat dapat dilihat dalam Pasal 88 Kitab Undang-Undang Hukum Pidana yang mengatakan, dikatakan ada permufakatan jahat, apabila dua orang atau lebih telah sepakat melakukan kejahatan. Dengan demikian sanksi yang dapat diberikan kepada PPAT Marlina Flora atas perbuatan Maladministrasi dalam pembuatan AJB Nomor 33/2004 adalah pemberhentian secara tidak hormat.

\section{PENUTUP}

\section{A. Kesimpulan}

Berdasarkan uraian analisis di atas, maka dapat ditarik kesimpulan sebagai berikut: 
1. Akibat hukum merupakan suatu akibat yang ditimbulkan oleh hukum karena suatu perbuatan yang dilakukan oleh subjek hukum. Dalam menjalankan tugas, wewenang dan kewajibannya PPAT harus memiliki prinsip kehati-hatian. Prinsip kehati-hatian ini diperlukan agar tidak terjadi penyimpangan dalam arti tidak melakukan prosedur dengan benar. Penyimpangan ini disebut dengan Perbuatan Maladministrasi. Maka dapat diambil kesimpulan bahwa Perbuatan Maladministrasi disebabkan karena kelalaian akibat ketidakpedulian terhadap wewenang yang telah diberikan kepadanya., penyimpangan prosedur, penyimpangan wewenang dan perbuatan sewenang-wenang untuk mencapai tujuan daripada kewenangannya.

PPAT memiliki tugas pokok yang diatur dalam Peraturan Pemerintah Nomor 37 tahun 1998 tentang Peraturan Jabatan Pejabat Pembuat Akta Tanah Pasal 2 ayat (1) yaitu melakukan sebagian kegiatan pendaftaran tanah dengan membuat akta mengenai perbuatan hukum. Atau dengan kata lain PPAT bertugas untuk membantu Badan Pertanahan Nasional megenai Pendaftaran Tanah. Perbuatan hukum yang dimaksud terdapat dalam ayat (2) yaitu jual-beli, tukar menukar, hibah, pemasukan kedalam perusahaan, pembagian hak bersama, pemberian Hak Guna Usaha/ Hak Pakai atas tanah Hak Milik, Pemberian Hak Tanggungan dan Pemberian Kuasa membebankan Hak tanggungan.

Mengenai Peralihan hak atas tanah melalui jual-beli, salah satunya adalah pembuatan Akta Jual Beli di hadapan PPAT, dan syarat utamanya terdapat dalam Pasal 22 Peraturan Pemerintah Nomor 37 tahun 1998 tentang Peraturan Pejabat Pembuat Akta Tanah yaitu akta yang dibuat PPAT harus dibacakan atau dijelaskan isinya kepada para pihak dengan dihadiri oleh sekurang-kurangnya dua orang saksi. Jika tidak memenuhi syarat-syarat tersebut maka akta yang dibuat adalah batal demi hukum. Dalam Kasus ini, Putusan Hakim sudah sesuai dengan permohonan penggugat dan peraturan Perundang-Undangan yang berlaku, karena tidak ada kesepakatan yang terjadi antara Penggugat dan Tergugat mengenai jual beli tanah SHM Nomor 494 tersebut dan tidak adanya kausa yang halal mengenai perbuatan hukum pemindahan hak atas tanah ini, karena NG Hui Jang dan PPAT 
Marlina Flora telah melakukan permufakatan jahat sebagai sindikat penipuan sertipikat.

2. Dalam rangka melaksanakan tugas jabatan para PPAT serta PPAT Pengganti ataupun dalam kehidupan sehari-hari, PPAT wajib berkepribadian baik dan menjunjung tinggi martabat dan kehormatan PPAT, menjunjung tinggi dasar negara dan hukum yang berlaku serta bertindak sesuai dengan makna sumpah jabatan dan kode etik bekerja dengan penuh rasa tanggung jawab, mandiri serta dituntut profesional sesuai Keputusan Menteri Agraria dan Tata Ruang/Kepala Badan Pertanahan Nasional Nomor 112/KEP-4.1/IV/2017 tanggal 27 April 2017 tentang Peraturan Kode Etik Ikatan Pejabat Pembuat Akta Tanah Pasal 3.

Sanksi yang diberikan kepada PPAT yang melakukan perbuatan maladministrasi diatur dalam Peraturan Kepala Badan Pertanahan Nasional Republik Indonesia Nomor 1 Tahun 2006 tentang Ketentuan Pelaksanaan Peraturan Pemerintah Nomor 37 Tahun 1998 tentang Peraturan Jabatan Pejabat Pembuat Akta Tanah Pasal 28 antara lain pemberhentian secara hormat dan pemberhentian secara tidak hormat. Pemberhentian secara tidak hormat karena telah melakukan Pelanggaran berat sebagaimana yang dimaksud antara lain:

a. Membantu melakukan permufakatan jahat yang mengakibatkan sengketa atau konflik petanahan

b. Melakukan pembuatan akta sebagai permufakatan jahat yang mengakibatkan sengketa atau konflik pertanahan

c. Melakukan pembuatan akta diluar daerah kerjanya kecuali yang dimaksud dalam Pasal 4 dan Pasal 6 ayat (3)

d. Memberikan keterangan yang tidak benar didalam akta yang mengakibatkan sengketa atau konflik pertanahan

e. Membuka kantor cabang atau perwakilan atau bentuk lainnya yang terletak diluar dan atau didalam daerah kerjanya sebagaimana dimaksud dalam Pasal 46

f. Melanggar sumpah jabatan sebagai PPAT

g. Pembuatan akta PPAT yang dilakukan, sedangkan diketahui oleh PPAT yang bersangkutan bahwa para pihak yang berwenang melakukan 
perbuatan hukum atau kuasanya sesuai peraturan perundang-undangan tidak hadir dihadapannya.

h. Pembuatan akta mengenai hak atas tanah atau Hak Milik atas Satuan Rumah Susun yang oleh PPAT yang bersangkutan diketahui masih dalam sengketa yang mengakibatkan penghadap yang bersangkutan tidak berhak melakukan untuk perbuatan hukum yang dibuktikan dengan akta

i. PPAT tidak membacakan aktanya dihadapan para pihak maupun pihak yang belum atau tidak berwenang melakukan perbuatan sesuai akta yang dibuatnya.

j. PPAT membuat akta dihadapan para pihak yang tidak berwenang melakukan perbuatan hukum sesuai akta yang dibuatnya

k. PPAT membuat akta dalam masa dikenakan sanksi pemberhentian sementara atau dalam keadaan cuti.

Berdasarkan kasus ini, PPAT Marlina Flora haruslah di berhentikan secara tidak hormat karena telah terbukti melakukan pelanggaran berat berupa permufakatan jahat yang mengakibatkan konflik atau sengketa tanah. PPAT Marlina Flora juga telah membuat akta berdasarkan permufakatan jahat yang mengakibatkan konflik atau sengketa pertanahan. PPAT Marlina Flora juga tidak melakukan penandatanganan di hadapan para pihak, sudah pasti tidak membacakan isi akta dihadapan para pihak.

\section{B. Saran}

Dari kesimpulan diatas, maka saran yang dapat diberikan adalah:

1. Bagi Penggugat agar lebih jelih dalam melakukan perbuatan hukum pinjaman dana dalam memberikan jaminan sertipikat. Bagi PPAT, dalam melakukan pembuatan akta haruslah sesuai dengan prosedur yang berlaku agar tidak mengakibatkan akibat hukum yang dapat merugikan para pihak.

2. PPAT merupakan profesi yang luhur, agar kiranya dimasa yang akan datang harus lebih ditingkatkan lagi pengawasan dan pembinaan untuk dapat menjadi seorang PPAT, bila perlu Menteri yang akan mengangkat seorang PPAT harus diseleksi berdasarkan nilai-nilai moral dan kedisplinan yang tinggi. Agar tidak menurunkan martabat luhur sebagai seorang PPAT. 


\section{DAFTAR PUSTAKA}

\section{A. Buku-Buku}

Al-Rashid, Harun. Sekilas Tentang Jual-Beli Tanah Berikut PeraturanPeraturannya. Jakarta: Ghalia Indonesia, 1986.

Efendi, A'an dan Freddy Poernomo. Hukum Administrasi. Jakarta: Sinar Grafika, 2017.

Harsono, Boedi. Hukum Agraria Indonesia: Sejarah Pembentukan UndangUndang Pokok Agraria,Isi dan Pelaksanaannya. Cetakan ke-3. Jakarta: Universitas Trisakti, 2016.

Marzuki, Peter Mahmud. Penelitian Hukum. Edisi Pertama. Cetakan Ke-2. Jakarta: Kencana Prenada Media Group, 2006.

Penelitian Hukum. Edisi Revisi. Cetakan Ke-9. Jakarta: Kencana Prenada Media Group, 2016.

Santoso, Urip. Pejabat Pembuat Akta Tanah (Perspektif Regulasi, Wewenang, dan sifat Akta). Cetakan-1. Jakarta: Prenadamedia Group, Januari 2016.

Soepomo, R.D. Hukum Perdata Adat Jawa Barat. Cetakan Ke- 2. Jakarta: Penerbitan Djambatan, 1982.

\section{B. Undang-Undang}

Indonesia. Undang-Undang Nomor 37 Tahun 2008 tentang Ombudsman Republik Indonesia (Lembaran Negara Republik Indonesia Tahun 2008 Nomor 139, Tambahan Lembaran Negara Republik Indonesia Nomor 4899).

Peraturan Pemerintah Nomor 24 Tahun 1997 tentang Pendaftaran Tanah (Lembaran Negara Republik Indonesia Tahun 1997 Nomor 59, Tambahan Lembaran Negara Republik Indonesia Nomor 3696).

Peraturan Pemerintah Nomor Peraturan Pemerintah Nomor 37 Tahun Tahun 1998 tentang Peraturan Jabatan Pejabat Pembuat Akta Tanah (Lembaran Negara Republik Indonesia Tahun 1998 Nomor 52, Tambahan Lembaran Negara Republik Indonesia Nomor 3746).

Peraturan Pemerintah Nomor Peraturan Pemerintah Nomor 24 Tahun 2016 tentang Perubahan Atas Peraturan Pemerintah Nomor 37 Tahun 1998 tentang Peraturan Jabatan Pejabat Pembuat Akta Tanah (Lembaran Negara Republik Indonesia Tahun 2016 Nomor 120, Tambahan Lembaran Negara Republik Indonesia Nomor 5893). 
Cecyllia Tamara B. Schouten \& Hanafi Tanawijaya Tentang Peraturan Jabatan PPAT Jo. Peraturan Pemerintah Nomor 37 Tahun 1998

Tentang Peraturan Jabatan PPAT (Studi Kasus Putusan Pengadilan Negeri Jakarta Selatan Nomor 129/Pdt.G/2016/PN.Jkt.Sel.)

\section{Jurnal}

Jurnal Ius. “Kajian Hukum dan Keadilan”. Vol. IV. ( April 2016). 